Vol. 24, No. 1, Januari 2021, hlm. 1-10

p-ISSN: 1410-9344; e-ISSN: 2549-5631

WARTA LPM

homepage: http://journals.ums.ac.id/index.php/warta

\title{
PKM Edukasi dan Neurorestorasi pada Pasien Pasca Stroke di Praktik Fisioterapi MJ_9 Fisioterapi Center
}

\author{
${ }^{1}$ Umi Budi Rahayu, ${ }^{2}$ Ambarwati \\ Program Studi Profesi Fisioterapi, Fakultas Ilmu Kesehatan, Universitas Muhammadiyah Surakarta

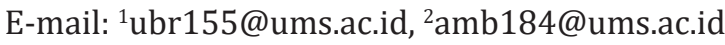

\section{Article Info}

Submitted: 15 January 2020

Revised: 7 April 2020

Accepted: 3 June 2020

Published: 12 December 2020

Keywords: Education,

Rehabilitation,

Neurorestoration,

Physiotherapy, Post-Stroke
Kata kunci: Edukasi,

Rehabilitasi, Neurorestorasi, Fisioterapi, Pasca Stroke

\section{Abstract}

Hospital and clinics/ physiotherapy services have limited time and place in post-stroke care, while not all patients are able to continue treatment, especially outpatients from hospitals. It is necessary to place physiotherapy services both in independent practice and at the patient's home with adequate understanding and ability to do so as to optimize the function and quality of life post-stroke. The problem was how to provide education and neurorestoration to optimize patient function after stroke. The aim of the activity was to provide community service programs on education and neurorestoration in post-stroke at the Physiotherapy Practice MJ_9 Physiotherapy Center and at the patient's home. The methods of the activities was in the form of information education through leaflets for patients and families. The next activity was to provide neurorestoration of post-stroke patients by physiotherapists both at home and in the MJ_9 Physiotherapy Practice guided by video. Neurorestoration activities carried out for 6 visits, 2 times a week. Observation of progress was made for muscle strength on the lesion side using Motricity Index, ability to roll using trunk control test, ability to walk using 10 MWT, balance using Berg Balance Scale and functional ability using Barthel Index. The results of the activities was the discovery of 15 post-stroke patients with heterogeneous conditions, ranging from just lying in bed to mild functional impairment. Gradual and appropriate counseling and administration of neurorestoration can increase muscle strength, rolling ability, balance, which has a positive effect on improving functional ability and improving quality of life. In general, it was concluded that community education and neurorestoration in poststroke patients are able to provide understanding and improvement of the patient's function and quality of life.

Abstrak
Pelayanan rumah sakit maupun klinik/layanan fisioterapi mempunyai
keterbatasan waktu dan tempat dalam perawatan pasca stroke,
sementara tidak semua pasien mampu melanjutkan perawatan


khususnya rawat jalan di rumah sakit. Perlu tempat layanan fisioterapi baik di praktik mandiri maupun di rumah pasien sendiri dengan pemahaman dan kemampuan yang memadahi untuk melakukannya sehingga dapat mengoptimalkan fungsi dan kualitas hidup pasca stroke. Permasalahannya adalah bagaimana memberikan edukasi dan neurorestorasi untuk optimalisasi fungsi pasien pasca stroke. Tujuan kegiatan memberikan program pengabdian kepada masyarakat tentang edukasi dan neurorestorasi pada pasien pasca stroke di Praktik Fisioterapi MJ_9 Fisioterapi Center dan di rumah pasien. Metode kegiatan edukasi berupa penyuluhan informasi melalui leaflet untuk pasien dan keluarga. Kegiatan selanjutnya memberikan neurorestorasi pasien pasca stroke oleh fisioterapis baik di rumah maupun di Praktik Fisioterapi MJ_9 di pandu dengan video. Kegiatan latihan dengan neurorestorasi dilakukan selama 6 kali kunjungan, seminggu 2 kali. Pengamatan perkembangan dilakukan untuk kekuatan otot pada sisi yang lesi dengan Motricity Index, kemampuan berguling dengan trunk control test, kemampuan jalan dengan 10 MWT, keseimbangan dengan Berg Balance Scale dan kemampuan fungsional dengan Barthel Index. Hasil dari kegiatan ini adalah ditemukannnya 15 pasien pasca stroke dengan kondisi yang heterogen, mulai dari hanya berbaring di tempat tidur sampai dengan kondisi gangguan kemampuan fungsional yang ringan. Penyuluhan dan pemberian neurorestorasi yang dilakukan secara dini, bertahap, dan tepat mampu meningkatkan kekuatan otot, kemampuan berguling, keseimbangan, yang membawa pengaruh positif untuk peningkatan kemampuan fungsionalnya serta peningkatan kualitas hidupnya. Secara umum disimpulkan bahwa PKM edukasi dan neurorestorasi pada pasien pasca stroke mampu memberikan pemahaman dan peningkatan fungsi serta kualitas hidup pasien.

\section{PENDAHULUAN}

Saat ini pelayanan untuk pasien stroke sangat terbatas, sementara jumlah penderita semakin meningkat, setidaknya berdasarkan survey ada sekitar 20 pasien belum semua mendapatkan pelayanan yang optimal dan tidak mandiri. Kondisi ini sangat tidak menguntungkan terutama untuk jangka panjang karena akan menimbulkan berbagai gejala sisa maupun komplikasi lanjut. Berdasarkan hasil analisa menunjukkan ternyata tidak semua pasien mampu keluar rumah untuk pemulihan fisik dan kemandiriannya karena berbagai alasan, diantaranya ketidakmampuan fisik, masalah keuangan, sampai dengan keterbatasan dan ketidaktahuan tentang perawatan kemandirian pasca stroke baik dari pasiennya sendiri maupun dari pihak keluarga.
Sudah diketahui bahwa kebanyakan kasus kesehatan yang terjadi pada masa kini dan diprediksikan akan terus meningkat di masa yang akan datang adalah penyakit-penyakit degeneratif, penyakit sebagai akibat gangguan metabolisme, dan penyakit tidak menular seperti stroke. Angka kejadian stroke semakin lama semakin meningkat. Kasus ini tidak hanya terjadi pada orang tua saja tetapi juga sudah banyak terjadi pada usia-usia produktif (usia 40 sampai 50 tahun) sebagai akibat adanya komplikasi karena gangguan metabolisme. Seperti hasil survey yang telah dilakukan sebelumnya, setidaknya ada beberapa masyarakat di wilayah Surakarta yang terkena stroke dan tidak semuanya mendapatkan pelayanan yang optimal sehingga banyak pasien yang mengalami keterbatasan fungsi bahkan ada beberapa yang tidak mampu melakukan aktivitasnya secara 
mandiri. Kebanyakan jenis stroke yang ada di masyarakat adalah stroke iskemia, yang bisa terjadi karena berbagai mekanisme antara lain thrombosis, emboli maupun penurunan perfusi sistemik (Caplan, 2009).

Stroke, seperti dikemukakan WHO merupakan suatu penyakit yang ditandai dengan berkembang cepatnya tanda fokal maupun global karena adanya gangguan fungsi otak yang berlangsung lebih dari 24 jam karena gangguan vaskularisasi yang mengakibatkan kematian sel-sel saraf di otak (Caplan, 2009; Fisher et al., 2013). Kerusakan otak bisa terjadi pada beberapa area di otak, seperti yang sering terjadi pada stroke yaitu kerusakan pada cortex sensomotor pada area subcortical dan/atau cerebellum yang dapat menghasilkan hilangnya kontrol dan kemampuan motorik serta defisit sensorik dan proprioceptive (Morris et al., 2013).

Akibat lanjut dari berbagai mekanisme ini secara umum akan terbagi menjadi 3 domain, yaitu adanya kelemahan separuh anggota badan, kecacatan dengan spastisitas yang tinggi bahkan sampai dengan terjadi deformitas berat yang membentuk pola patologis. Khususnya problem kelemahan terjadi karena defisit fisiologik spesifik seperti penurunan kemampuan motorik, kekuatan, koordinasi, sensasi, bahasa maupun memori (Rahayu, 2014). Sedangkan keterbatasan lanjut berupa ketidakmampuan dalam berpartisipasi di lingkungan sekitarnya (Goldstein, 2009). Kondisi yang semakin menurun akan memperburuk keadaan seperti keluhan pusing, merasa tidak seimbang, mudah jatuh, koordinasi yang jelek, maupun merasakan problem berjalan (Harvey, 2009), di mana berjalan menjadi lebih lambat, merasakan tungkai lebih berat dan sulit untuk diangkat maupun merasa goyang/tidak seimbang. Perburukan kondisi pasien ini juga dipengaruhi oleh semakin meningkatnya usia (Kelly-Hayes et al., 2003), area lesi maupun luas lesi (Stein, 2009), kontrol motorik, defisit sensorik, dan proprioseptif (Morris et al., 2013). Meskipun demikian, berbagai upaya bisa dilakukan untuk melimitasi gangguan yang semakin berat dan mengoptimalkan kemandiriannya melalui berbagai hal, termasuk latihan untuk regenerasi saraf.
Latihan untuk regenerasi sel saraf ini sangat diperlukan pasca stroke. Salah satu bentuk latihan pasca stroke dikenal dengan istilah neurorestorasi. Neurorestorasi adalah suatu upaya untuk memulihkan lesi saraf berdasarkan mekanisme regenarasi sel saraf. Adanya regenerasi sel saraf ditandai dengan meningkatnya proses neurogenesis, angiogenesis, dan oligodendrogenesis sebagai upaya perbaikan saraf (Chen et al., 2014). Neurorestorasi dengan pendekatan pembelajaran motorik dilakukan untuk setiap fase stroke untuk meningkatkan neuroplastisitas dan reorganisasi otak setelah stroke (Saver et al., 2009). Pemulihan ini terjadi karena adanya resolusi edema dan kembalinya sirkulasi darah pada area penumbra yang mengalami iskemia. Pemulihan ini akan terjadi maksimal disepanjang periode setelah fase akut sampai dengan 2 hingga 6 minggu. Hal yang menarik bahwa stimulasi otak seperti stimulasi dalam bentuk latihan mampu memunculkan potensi plastis adaptif yang mempercepat proses rehabilitasi stroke, karena pada saat cortex motorik primer (M1) dan corticospinal rusak maka area premotor ipsilesional (PMAs) bisa digunakan menjadi penggantinya (Plow et al., 2014).

Sebagaimana diketahui bahwa penyakit stroke merupakan penyakit saraf yang memerlukan waktu dan stimulus untuk pemulihan sel-sel saraf, serta mempunyai potensi komplikasi sekunder untuk jaringan otot maupun organ-organ dalam (kardiorespirasi, vaskuler, internis) apabila tidak ditangani dengan paripurna (Rahayu, 2015). Solusi berbagai intervensi fisioterapi bisa dilakukan seperti penerapan Neuro Muscular Taping (Rahayu, 2015) maupun intervensi pembelajaran motorik seperti neurorestorasi (Rahayu, 2016; Rahayu 2017). Intervensi yang diberikan terapis/ fisioterapi disesuaikan tahapan pemulihan stroke. Tahapan pemulihan stroke secara umum terbagi menjadi beberapa fase, yaitu fase akut yang terjadi sesaat setelah terjadinya serangan, biasanya pasien ditangani oleh dokter untuk mencegah perburukan keadaan, setelah itu terjadi fase post akut. Pada fase ini kondisi pasien sudah berangsur stabil, biasanya akan dirawat di rumah sakit dan dilakukan observasi sampai 1 minggu, dan setelah itu pasien diperkenankan 
untuk pulang. Pada saat pasien masih di rumah sakit kondisinya masih terpantau dengan baik, namun yang menjadi problem adalah setelah pulang dari rumah sakit, karena pasien masih harus menjalani fase rehabilitasi awal dan fase fungsional (KNGF Guideline, 2014). Pada fase inilah biasanya pasien maupun keluarga tidak bisa mengendalikan kondisi pasien sementara pihak rumah sakit tidak bisa memantau keadaan pasien selanjutnya. Problem yang lain adalah adanya tambahan beban terutama keuangan karena pemerintah tidak menanggung pembiayaan pasca keluar rumah sakit (home program atau edukasi di rumah).

Hal yang sering terjadi dan menjadi problem besar pasca stroke setelah pulang dari rumah sakit adalah keadaan pasien yang semakin memburuk setelah pulang kerumah, adanya ketergantungan sedang sampai dengan ketergantungan berat (problem kemandirian) atau bahkan sampai berujung pada kematian. Suatu keharusan dan menjadi hak pasien untuk mendapatkan penangan pada fase-fase ini sehingga optimalisasi kondisi serta kemandirian pasien bisa dicapai. Upaya harus dilakukan terutama bagaimana layanan untuk kelanjutan pasien pasca stroke bisa diupayakan dan dilakukan.

Terbatasnya pelayanan pasien stroke disebabkan pula oleh terbatasnya pusat layanan, termasuk klinik-klinik fisioterapi, yang sangat diperlukan pasca stroke. Tempat Praktik Fisioterapi MJ_9 Fisioterapi Center Solo sebagai salah satu pusat layanan optimalisasi kondisi pasca stroke menjadi terbatas dalam menangani pasien ini karena beberapa hal, diantaranya keterbatasan tenaga terutama untuk pasienpasien yang tidak mampu menjangkau tempat praktik fisioterapi yang memerlukan home visite. Demikian pula Praktik Fisioterapi MJ_9 Fisioterapi Center Solo, yang belum mampu menjangkau pasien pasca stroke karena keterbatasan tenaga dan ketidakmampuan pasien untuk datang ke tempat praktik fisioterapi.

Lokasi mitra dalam kegiatan pengabdian kepada masyarakat ini adalah Praktik Fisioterapi "MJ_9 Fisioterapi Center" Solo. Tempat praktik ini berdiri dengan SIP. No. 449/014/SIPF/20147 yang bertempat di Lantai 2 Apotek Taruna Sehat Jl. Jaya Wijaya Mojosongo Solo merupakan salah satu tempat praktik yang melayani berbagai gangguan yang indikasi diberikan fisioterapi termasuk optimalisasi pasien pasca stroke untuk wilayah Surakarta, terutama Surakarta bagian timur dan utara. Pelayanan fisioterapi berjalan cukup lancar, namun beberapa program pengembangan masyarakat belum bisa berjalan dengan lancar terutama program kesadaran hidup sehat di masyarakat melalui penyuluhan, deteksi dini, pemeriksaan umum, maupun pengembangan komunitas khususnya komunitas stroke untuk meningkatkan kualitas hidup pasiennya. Tempat praktik ini juga mempunyai salah satu program pengembangan masyarakat yang bertujuan untuk mengembangkan kesadaran masyarakat akan pentingnya menjaga kesehatan masyarakat melalui berbagai kegiatan antara lain penyuluhan, deteksi dini, pemeriksaan umum, dan pengembangan kader untuk melayani masyakarat wilayah Surakarta dalam memecahkan permasalahan penyakit, termasuk stroke.

Optimalisasi terapi yang fokus terutama untuk penanganan pasca stroke mutlak diperlukan, karena hampir semua pasien stroke mempunyai gejala sisa. Gejala sisa berupa gangguan motorik yang terjadi karena terapi yang tidak optimal akan berpotensi terjadinya komplikasi sekunder dari sistem musculoskeletal setelah pasien pulang dari rumah sakit. Kegiatan pengabdian ini akan sangat mendukung tempat praktik fisioterapi untuk mengoptimalkan kemandirian pasien pasca stroke dan akan sangat membantu pula bagi penyandang stroke dan keluarganya terutama setelah pulang dari rumah sakit, karena disamping akan fokus pengamatan perkembangan sampai dengan kemandirianya, masyarakat yang tidak mampu datang (baik karena keuangan, ketidakmampuan pasien, jarak, ketersediaan waktu, ketersediaan tenaga pendamping) akan dapat tertangani dengan baik. Selain itu kesempatan untuk memaksimalkan peran keluarga dapat dilakukan secara optimal.

Seperti dalam maksud kegiatan ini yang melibatkan unsur keluarga, berupa pemberian pendidikan dan edukasi untuk keluarga 
memungkinkan dapat mengoptimalkan dan memantau kondisi umum serta kemandirian pasien. Keluarga bisa juga melakukan hal-hal sederhana yang sangat berarti bagi pasien, misalnya posisioning, melatih dengan latihanlatihan sederhana. Kegiatan-kegiatan lanjutan berupa pengajaran fisik melalui neurorestorasi dilakukan untuk menunjang aktivitas serta kemampuan fungsional keseharian pasien pasca stroke, baik oleh keluarga, caregiver, maupun pasien sendiri. Sehingga tujuan dari program ini adalah memberikan penyuluhan dan edukasi untuk keluarga dan pasien serta memberikan intervensi neurorestorasi berupa latihan dengan pembelajaran motorik untuk pasien pasca stroke dalam rangka meningkatkan kemandirian pasien, yang akan diukur dan dievaluasi dengan berbagai alat yang terukur.

\section{METODE}

Metode pelaksanaan pengabdian kepada masyarakat edukasi dan neurorestorasi untuk pasien pasca stroke di Praktik Fisioterapi MJ_9 Fisioterapi Center Solo meliputi penyuluhan, edukasi untuk pasien, serta neurorestorasi untuk pasien pasca stroke. Waktu pelaksanaan pengabdian dari bulan Juni sampai Nopember 2019. Secara umum tahapan pengabdian diawali dengan penyuluhan, intervensi neurorestorasi untuk pasien serta pemeriksaan kondisi fisik, kemampuan fungsional dan kualitas hidup pasien baik sebelum maupun sesudah diberikan intervensi neurorestorasi untuk mengevaluasi kemajuan pasien. Berbagai alat dan bahan dipersiapkan untuk mendukung kegiatan ini seperti tensi, stetoskop, oksimetri, elastic tape, sinar infra merah, timbangan berat badan, tinggi badan, handuk, protokol neurorestorasi, berbagai bahan perlindungan diri seperti hand sanitizer serta berbagai form pemeriksaan seperti kekuatan otot, rotasi vertebrae, test keseimbangan, test kemampuan berjalan, kemampuan fungsional serta kualitas hidup.

Penyuluhan diberikan kepada pasien dan keluarga. Penyuluhan bersifat kolektif (secara bersama-sama) maupun pribadi (konsultasi sesuai dengan spesifik problem yang ada pada pasien). Edukasi berupa penjelasan-penjelasan dan peragaan praktik mengenai hal-hal yang harus dipahami terkait stroke dan kesembuhan pasien oleh fisioterapis. Neurorestorasi berupa intervensi atau terapi spesifik yang dilakukan terprogram oleh pasien pasca stroke, baik di rumah maupun di tempat praktik fisioterapi.

Penyuluhan diperlukan untuk memberikan gambaran tentang stroke dan pencegahannya, baik untuk keluarga yang memberikan dukungan dan merawatnya maupun untuk pasien sendiri untuk memberikan semangat dan gambaran hal-hal yang harus dilakukan dalam aktivitasnya secara benar. Edukasi diberikan untuk pasien terutama untuk mengajarkan hal-hal aktivitas yang bisa dilakukannya sendiri di rumah. Sedangkan neurorestorasi merupakan suatu program latihan untuk menuju kemandiriannya. Untuk kemandirian diperlukan beberapa latihan dari latihan penguatan untuk sisi yang layuh maupun untuk pengautan otot perut, latihan kemampuan berguling, kemampuan bangun secara mandiri, latihan keseimbangan duduk dan berdiri serta latihan berjalan.

Alat ukur untuk mengamati peningkatan penguatan otot yang layuh dengan Motricity Index, alat untuk mengukur kemampuan trunk rolling untuk membangkitkan kemampuan berguling dengan Trunk Control Test (TCT), kemampuan keseimbangan dengan Berg balance Scale (BBS), kemampuan berjalan dengan 10 MWT, kemampuan fungsional dengan Barthel Index, dan kualitas hidup dengan Stroke Specific Quality of Life Scale (SS-QOL).

Kegiatan pelaksanaan kegiatan secara umum digambarkan sebagai berikut:

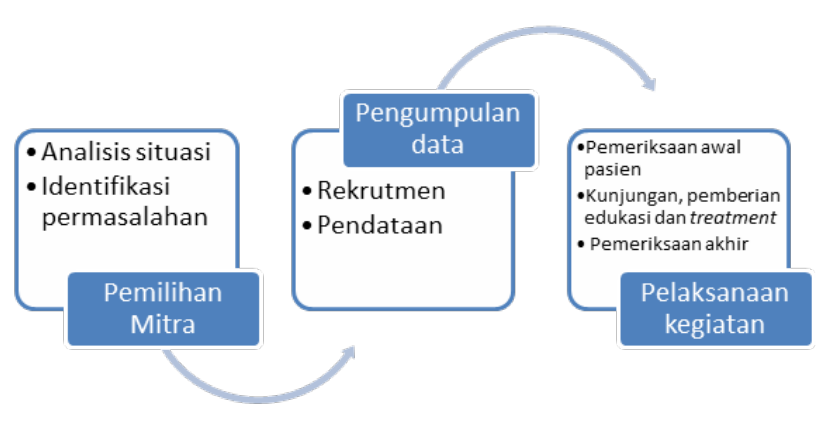

Gambar 1. Metode kegiatan 
Pembahasan kegiatan dijelaskan secara deskriptif meliputi pelaksanaan kegiatan, baik kegiatan penyuluhan untuk keluarga pasien dan pasiennya, pemberian intervensi neurorestorasi yang berupa latihan dengan pembelajarn motorik dan terutama capaian tujuan yang merupakan hasil dengan melihat nilai-nilai untuk kemandirian pasien pasca stroke melalui berbagai pemeriksaan yaitu peningkatan kekuatan otot pada anggota gerak yang layuh, kemampuan berguling, kemampuan mempertahankan keseimbangan, kemampuan bangkit dari tempat tidur dan tempat duduk, kemampuan berjalan, serta kemampuan melakukan aktivitas fungsionalnya sehingga kualitas hidupnya meningkat. Evaluasi dari berbagai indikator capaian ini dilakukan setelah 6 kali terapi. Terapi dilakukan 2 kali dalam satu minggu.

\section{HASIL DAN PEMBAHASAN}

Pelaksanaan PKM terkait dengan pendataan pasien dilakukan secara bertahap. Pertama kali pendataan didapatkan 8 pasien dengan kondisi yang bervariasi. Pendataan dilakukan secara berjenjang tergantung adanya pasien stroke. Pendataan berikutnya ada 4 pasien dan terakhir didapatkan 3 pasien. Pendataan dilakukan berdasarkan data sejumlah pasien yang berkonsultasi ke tempat praktik fisioterapi MJ_9 Fisioterapi Center, namun kebanyakan adalah pasien dengan program dirumah karena keterbatasannya. Sehingga fisioterapis mendatangi pasien dirumah.
Program edukasi dilakukan dengan cara mengundang keluarga pasien untuk menghadiri penyuluhan dan edukasi tentang stroke dan penanganannya. Penyuluhan dan edukasi dilakukan secara langsung di Laboratorium Fisioterapi UMS, melalui media leaflet dengan judul "kenali stroke" dan "neurorestorasi pasca stroke" yang telah dibuat serta pemberian edukasi yang dilakukan secara langsung di rumah untuk keluarga dan pasien pada saat kunjungan rumah.

Penyuluhan dan edukasi yang dilakukan di Laboratorium Fisioterapi UMS dihadiri oleh keluarga pasien. Kegiatan ini diisi dengan ceramah tentang stroke dan patologi stroke, cara-cara mengenali stroke berulang, penjelasan upaya-upaya apa saja yang harus dilakukan ketika dicurigai adanya serangan ulang. Kegiatan juga disertai dengan penjelasan dan demonstrasi tentang posisioning yang benar, baik posisi saat tidur terlentang, tidur miring pada sisi yang sehat, pada sisi yang sakit, memperagakan cara duduk yang benar dari posisi tidur terlentang, duduk tegak, memperagakan duduk ke berdiri yang benar, cara berdiri yang benar untuk menjaga keseimbangannya maupun cara berjalan. Leaflet disebarluaskan sebagai informasi tentang hal-hal yang harus diketahui oleh masyarakat tentag stroke. Leaflet juga ditempatkan di Klinik MJ_9 Mojosongo untuk konsumsi sejumlah pengunjung yang menginginkannya. Gambaran kegiatan penyuluhan dan edukasi seperti terlihat pada Gambar 1 dan Gambar 2.

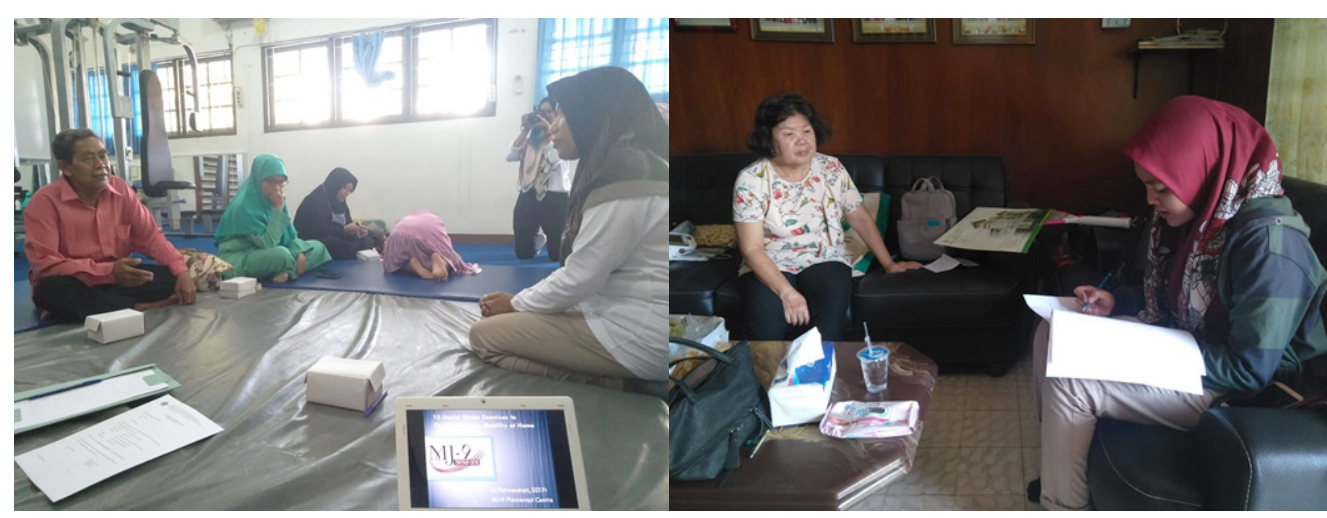

Gambar 1. Program penyuluhan, edukasi dan konsultasi untuk keluarga pasien di Laboratorium Fisioterapi UMS dan rumah pasien. 


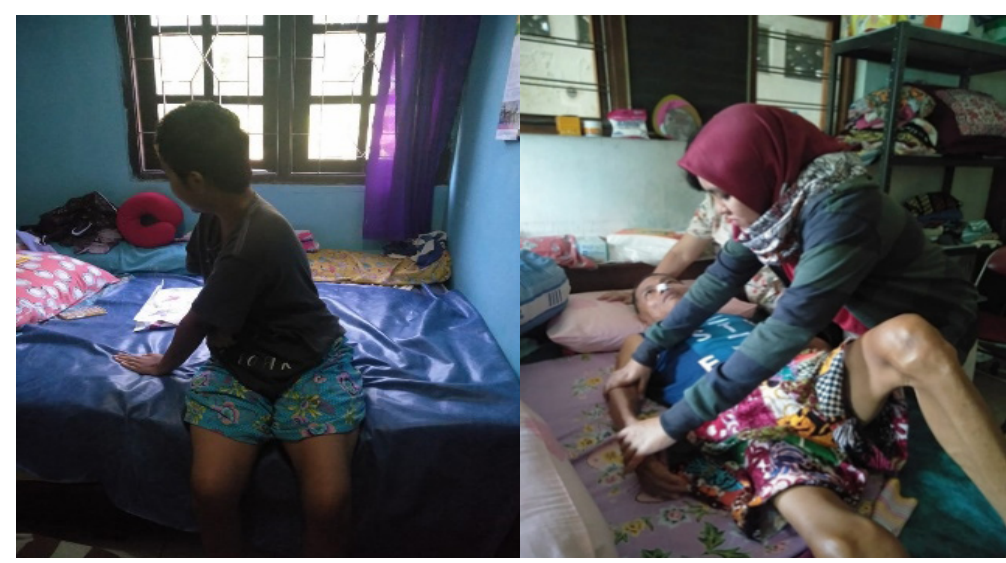

Gambar 2. Program neurorestorasi pasca stroke untuk pasien stroke di rumah pasien.

Kegiatan yang utama dari program pengabdiankepadamasyarakatadalahpemberian neurorestorasi untuk pasien pasca stroke sesuai dengan kemampuannya berdasarkan hasil pemeriksaan yang dilakukan sebelumnya. Pemeriksaan meliputi pemeriksaan tekanan darah, nadi maupun pemeriksaan kecukupan oksigen. Pemeriksaan ini dijadikan dasar untuk memberikan neurorestorasi dengan outcome kemandirian pasien dalam melakukan aktivitas kesehariannya, meliputi pemeriksaan kekuatan otot, rotasi vertebrae untuk melatih kemampuan berguling, test keseimbangan baik pada posisi duduk maupun berdiri, test kemampuan berjalan, kemampuan fungsional serta kualitas hidup pasien. Pemberian neurorestorasi dilakukan sesuai dengan kemampuan pasien dengan target kemandirian. Secara umum pemberian neurorestorasi untuk target kemandirian ini meliputi edukasi posisioning, melatih cara berguling, melatih cara bangun ke posisi duduk, latihan-latihan pada posisi duduk, melatih berdiri sendiri dari posisi duduk secara benar, serta latihan-latihan berdiri sampai dengan latihan jalan. Hasil dari perkembangan pasien, meliputi kekuatan otot, rotasi vertebrae, keseimbangan, kemampuan berjalan, kemampuan fungsional, dan kualitas hidup seperti dalam Tabel 1.

Secara umum didapatkan hasil bahwa dari sejumlah pasien yang ditangani menunjukkan hasil peningkatan kekuatan otot. Rata-rata kekuatan otot meningat menjadi 2,3 point dari maksimal nilai 4 point. Kemampuan rotasi vertebrae ini juga meningkat sampai 29,54 point. Kemampuan keseimbangan juga linier meningkat seiring dengan meningkatkan kemampuan berjalan maupun kemampuan fungsionalnya, yang mencapai kenaikan 11.07 point dihitung dengan Indek Barthel. Hal yang menarik adalah adanya peningkatan kualitas hidup pasien pasca stroke. Nilai kualitas hidup yang diukur dengan Stroke Specific Quality of Life Scale (SS-QOL) menunjukkan kenaikan nilai sampai dengan 11,73 point.

Tabel 1. Hasil perkembangan pasien pasca stroke sampai latihan ke-6

\begin{tabular}{|c|c|c|c|c|c|c|c|c|c|}
\hline \multirow{2}{*}{ Item } & \multicolumn{2}{|c|}{ Nilai minimal } & \multicolumn{2}{|c|}{ Nilai maksimal } & \multicolumn{2}{|c|}{ Median } & \multicolumn{2}{|c|}{ Mean } & \multirow{2}{*}{$\begin{array}{c}\text { Selisih } \\
\text { mean }\end{array}$} \\
\hline & T0 & T6 & T0 & T6 & T0 & T6 & T0 & T6 & \\
\hline Kekuatan otot & 0,5 & 15 & 1 & 16 & 8 & 9 & 6,8 & 9,1 & 2,3 \\
\hline Rotasi vertebrae & 0 & 100 & 24 & 100 & 37 & 100 & 53,06 & 82,6 & 29,54 \\
\hline Keseimbangan & 0 & 37 & 0 & 54 & 21 & 25 & 17,46 & 22,8 & 5,34 \\
\hline Kemampuan berjalan & 0 & 32 & 0 & 32 & 16 & 13 & 13,13 & 11,6 & 1,53 \\
\hline Kemampuan fungsional & 0 & 60 & 0 & 85 & 29 & 50 & 30,66 & 41,73 & 11.07 \\
\hline Kualitas hidup & 0 & 191 & 0 & 196 & 131 & 150 & 116,53 & 128,26 & 11,73 \\
\hline
\end{tabular}

Keterangan:

T0: Hasil pemeriksaan sebelum dilakukan neurorestorasi

T6: Hasil pemeriksaan setelah dilakukan neurorestorasi ke-6 
Kegiatan neurorestorasi dengan latihan pembelajaran motorik kebanyakan dilakukan kunjungan ke rumah pasien (home visite) karena keterbatasan pasien dalam melakukan mobilisasi maupun keterbatasan keluarga untuk mengantarkan ke tempat praktik fisioterapi. Neurorestorasi yang diberikan meliputi mengajarkan posisioning yang benar, baik pada posisi tidur terlentang maupun tidur miring untuk miring pada sisi yang sehat maupun yang sakit. Berbagai latihan, dari latihan berguling, latihan melakukan duduk secara mandiri dari posisi tidur, latihan keseimbangan pada posisi duduk, latihan melakukan duduk ke berdiri secara benar, latihan keseimbangan dan kestabilan pada posisi berdiri serta latihan berjalan. Pemberian sinar Infra Merah juga dilakukan untuk beberapa keluhan nyeri dan problem muscular, seperti pada tungkai, back, dan area otot-otot yang besar. Selain itu beberapa kasus diberikan elastic tape untuk rileksasi otot karena adanya ketegangan dan nyeri otot sebagaimana dikeluhkan pasien serta untuk stabilisasi sendi. Pemasangan elastic tape ini dengan teknik dekompresi sesuai dengan protokol Konsep NeuroMuscular Taping (NMT). Aplikasi NMT pada area leher belakang, bahu dan back jika ada keluhan nyeri, tangan dan kaki yang mengalami lesi.

Pemberian latihan motorik dengan neurorestorasi ini disesuaikan dengan tahapan atau fase dan keadaan pasien, serta berdasarkan hasil pemeriksaan yang dilakukan sebelumnya. Pemeriksaan yang dilakukan sebelum pemberian intervensi neurorestorasi adalah pemeriksaan tekanan darah, nadi, pemeriksaan kecukupan oksigen di otak serta pemeriksaan kemampuan fungsional pasca stroke. Hasil pemeriksaan awal ini sebagai pertimbangan dalam memberikan latihan motorik. Ada beberapa pasien yang menunjukkan hasil pemeriksaan yang tidak memungkinkan untuk dilakukan latihan neurorestorasi misalnya angka kecukupan oksigen di otak hanya 80 maupun tensi yang tinggia, maka latihan hanya berupa latihan pasif dan edukasi saja. Edukasi dan latihan posisioning selalu diberikan dan diingatkan kepada pasien untuk mencegah komplikasi lebih lanjut seperti decubitus, pneumonia. Posisioning ini dilakukan setiap dua jam sekali. Selain itu posisioning diberikan untuk stimulus atau rangsangan pada anggota tubuh yang mengalami lesi dan menghindari pola kompensasi yang sifatnya patologis.

Latihan lain yang sangat perlu adalah latihan berguling. Berguling sangat diperlukan untuk mempersipakan bangun secara mandiri. Latihan berguling meliputi gerakan rotasi bahu, panggul, dan tulang belakang. Selanjutnya latihan yang diberikan adalah melatih pasien ke posisi duduk. Latihan ke posisi duduk dilakukan terutama untuk dapat melakukan duduk dengan benar dan seimbang. Proses ke posisi duduk diperlukan latihan penguatan otot perut dan semua anggota gerak, terutama anggota gerak bagian atas dan bawah yang mengalami lesi. Duduk dengan seimbang ini harus dikuasai oleh pasien stroke. Duduk dengan seimbang dilakukan dengan stabilisasi postur dan duduk tegak sehingga pasien tidak mudah jatuh. Fisioterapis selalu memantau dan memastikan bahwa posisi duduk pasien telah dilakukan secara benar, tegak dan seimbang. Beberapa pasien menunjukkan durasi yang pendek dalam melakukan posisi duduk yang benar ini, sehingga fisioterapis harus selalu memberikan stimulus-stimulus untuk upaya tegaknya duduk ini.

Melatih ke posisi berdiri juga menjadi target latihan. Pasien pasca stroke harus mampu bangkit dari tempat duduk secara benar dan mandiri. Latihan ini diawali dengan memposisikan duduk pada posisi tegak, dan kedua kaki menapak penuh dan rata dengan lantai, selanjutnya pasien membungkukkan badan dan berdiri dengan tumpuan kedua kaki. Setelah pasien bisa menjaga keseimbangan berdiri, latihan selanjutnya adalah latihan berjalan. Berjalan adalah target terakhir terapi untuk mempersiapkan pasien melakukan aktivitas kesehariannya. Latihan berjalan diawali dengan latihan keseimbangan mempertahankan kedua tungkai dengan proporsi yang sama, latihan jinjit dan dilanjutkan dengan latihanlatihan berjalan dengan pola yang benar sesuai dengan fase analisa berjalan, dari fase heel strike sampai dengan toes off. Latihan berjalan dilakukan sesuai dengan fase awal ke fase akhir secara bertahap. Bila fase awal belum dikuasai maka fase awal ini diberikan desain bentukbentuk latihan yang mempermudah pasien untuk melakukannya. Penguasaan setiap fase berjalan sangat penting untuk menjaga keseimbangan 
aktivitasnya maupun untuk mendapatkan performa jalan yang baik.

Program nerurorestorasi dilakukan selam 6 kali yang secara umum dilakukan seminggu 2 kali. Sebelum, selama dilakukan neurorestorasi selalu dipantau dengan pemeriksaan kondisi umum seperti pemeriksaan tensi, nadi, dan oksimetri. Latihan fungsi motorik yang dilakukan dengan neurorestorasi ini menunjukkan hasil positif yang ditandai dengan peningkatan kekuatan otot terutama pada anggota gerak yang lesi, peningkatan kemampuan berguling, keseimbangan, kapasitas fisik dan kemampuan fungsional secara umum serta kualitas hidup yang semakin membaik sebagaimana dalam Tabel 1.

Selain evaluasi hasil kegiatan yang menunjukkan hasil yang positif terutama untuk pasien stroke terkait dengan fungsi motorik maupuan kualitas hidup, kegiatan ini juga menghasilkan berbagai luaran yang sangat bermanfaat tidakhanya untukpasien, masyarakat namun juga Program Studi Fisioterapi FIK UMS dalam kiprahnya berkontribusi untuk publik. Luaran yang telah dihasilkan dari kegiatan pengabdian masyarakat ini antara lain: brosur atau leaflet tentang stroke dan neurorestorasi pasca stroke yang bisa dimanfaatkan untuk pasien, klinik fisioterapi maupun masyarakat umum untuk memahami tentang stroke dan sebagai panduan sederhana dalam memberikan latihan untuk pasien stroke selama dirumah. Luaran yang lain adalah video neurorestorasi pasca stroke yang sudah diunggah di youtube, yang bisa juga digunakan sebagai panduan fisioterapis dan masyarakat umum dalam memberikan latihan pasca stroke. Kedua luaran ini juga di laporkan dalam catatan intelektual sebagai suatu karya (HaKI). Luaran terakhir adalah menggunggah hasil perkembangan pasien dalam sebuah tulisan yang dipublikasikan dalam sebuah jurnal.

\section{SIMPULAN}

Program neurorestorasi pasca stroke melalui latihan-latihan penguatan anggota tubuh yang layuh, latihan berguling, latihan bangun dan bangkit secara mandiri serta latihan berjalan mampu meningkatkan kemampuan kemandirian pasien pasca stroke. Kemampuan kemandirian ini sangat penting karena secara umum akan meningkatkan kualitas hidupnya.

Keberhasilan program yang telah dicapai pada kegiatan ini adalah tidak hanya perkembangan pasien yang semakin membaik dengan indikator kekuatan otot, rotasi vertebrae, keseimbangan, kemampuan berjalan dan kemampuan fungsionalnya namun juga dirumuskannya video neurorestorasi pasca stroke, leaflet sebagai panduan serta artikel yang bisa menjadi manfaat bagi pembaca. Rekomendasi untuk kegiatan pengabdian kepada masyarakat lanjut adalah meneruskan latihanlatihan aerobic dalam meningkatkan kebugaran jantung dan paru maupun mencegah komplikasi yang sangat mungkin terjadi, terutama untuk komplikasi paru dan muscular.

\section{UCAPAN TERIMA KASIH}

Ucapan terima kasih disampaikan kepada Ristekdikti yang telah mendanai kegiatan ini, tempat praktik fisioterapi MJ_9 Fisioterapi Center yang telah bersedia menjadi mitra dan sepakat untuk membentuk komunitas stroke, LPPI Universitas Muhammadiyah Surakarta yang telah menfasilitasi kegiatan ini, Laboratorium Fisioterapi FIK UMS yang telah menyediakan tempat dan fasilitasnya untuk pengembangan program neurorestorasi pasca stroke, sejumlah pasien pasca stroke yang telah berpartisipasi aktif dalam kegiatan ini serta sejumlah enumerator yang telah aktif membantu program ini.

\section{DAFTAR PUSTAKA}

Caplan, LR. (2009). Caplan's STROKE: A Clinical Approach. Fourth ed. Saunders Elsevier.

Chen, J., Venkat, P., Zacharek, A. \& Chopp, M. (2014). Neurorestorarive Therapy for Stroke, 8 (June), 1-12.

Doi: 10.3389/fnhum.2014.00382. 
Rahayu dan Ambarwati - PKM Edukasi dan Neurorestorasi pada Pasien Pasca Stroke ...

Donnan, GA., Fisher, M., Macleod, M., \& Davis, SM. (2008). Stroke. Lancet. www.thelancet.com, 371.

Fisher, A., Martin, J., Srikusalaukul, W. \& Davis, M. (2013). Trends in Stroke Survival Incidence Rates in Older Australians in The New Millennium and Forecasts into The Future. J Stroke Cerebravos Dis, 5, 1-12.

Goldstein, LB. (2009). Stroke Recovery and Rehabilitation. Handbook of Clinical Neurology, 94 (3rd series), 1327-1337.

Harvey, RL. (2009). Cerebral Stroke Syndrome dalam Stroke Recovery \& Rehabilitation. DemosMedical. New York.

Kelly-Hayes, M., Beiser, A., Kase, S., Scaramucci, A., D’Agostino, RB. \& Serigala, PA. (2003). The influence of Gender and Age on Disability Following Ischemic Stroke: the Framingham Study. J Stroke Cerebrovasc Dis, 12 (3), 119-126.

KNGF Guideline. (2014). Stroke. Royal Dutch Society for Physical Therapy.

Morris, JH., Van, WF., Joice, S. \& Donaghy, M. (2013). Predicting Health Related Quality of Life 6 Months After Stroke: The Role of Anxiety and Upper Limb Dysfunction. Disabil Rehabil, 35 (4), 291-299.

Plow, EB., Cunningham, DA., Varnerin, N. \& Machado, A. (2014). Rethinking Stimulation of The Brain in Stroke Rehabilitation: Why Higher Motor Areas Might Be Better Alternatives for Patient with Greater Impairments. Neuroscience. Doi: 10.1177/1073858414537381.

Rahayu, UB. (2014). Laporan Penelitian Harmonisasi Otak untuk Meningkatkan Kemampuan Memori dan Kognitif Pasien Pasca Stroke.

Rahayu, UB (2015). NeuroMuscular Taping untuk Meningkatkan Kemampuan Fungsional Pasien Pasca Stroke. International Conference of Medical and Health Sciences and Life Sciences Conference. Yogyakarta.

Rahayu, UB., Wibowo, S., Setyopranoto. I. (2017). Neurorestorasi untuk Meningkatkan Kadar BDNF, Keseimbangan dan Kemampuan Fungsional Pasien Pasca Stroke Iskemia. Disertasi. Universitas Gadjah Mada Yogyakarta.

Saver, JL. (2009). Target Brain: Neuroprotection and Neurorestoration in Ischemic Stroke. Rev Neurol Dis, 7, 14-21.

Stein, JH., Macho, RF., Winstein, JC. \& Zorowitz, RD. (2009). Stroke Recovery \& Rehabilitation. Demos Medical Publising. New York. 